TP Periodica Polytechnica Civil Engineering

62(4), pp. 1030-1038, 2018

https://doi.org/10.3311/PPci.11737

Creative Commons Attribution (i)

REVIEW ARTICLE

\section{Review of Research on the Application of Ferrocement in Composite Precast Slabs}

\author{
Yavuz Yardim ${ }^{1}$
}

Received 21 November 2017; Revised 27 March 2018; Accepted 25 April 2018

\begin{abstract}
Ferrocement has had a long history since it was first patented in 1856. Its significant benefits as construction material have been proven with numerous theoretical and experimental studies throughout the world for many years. This paper presents a comprehensive review of the studies on mechanical properties of ferrocement as used in precast and composite precast slabs. Additionally, this paper identifies and prioritizes the most advantageous designs for precast and composite precast ferrocement slabs and reviews the improved characteristics of ferrocement in comparison to traditional reinforced concrete concerning first crack load, ductility, capacity, whole-life cost benefits, and versatile application. Flexible options for different types of applications with its thin structural form provided by ferrocement and its contribution to the first crack load and ductility were discussed. The paper concludes by summarizing success-full uses and the advantages of ferrocement composite applications in precast structures.
\end{abstract}

Keywords

ferrocement, precast, composite slab, wire mesh

\footnotetext{
1 Department of Civil Engineering

School of Engineering,

Edinburgh University, The King's Buildings EH9 3FB

*Corresponding author, email: yyardim@ed.ac.edu
}

\section{Introduction}

Composite structures combine two or more materials in a structure to provide tangible benefits and a versatile solution to suit different applications. Each material is chosen due to its core function in the structure. A composite system reduces the unnecessary and unwanted material properties, such as weight and cost, without sacrificing required capacity. An optimum solution can be achieved with a rich option of different material properties. Therefore, many systems have been tried by researchers to use the advantages of composite structures. However, it is challenging to get favorable properties, such as a lightweight, strong, easy application and cheapness all in one material. Therefore, selection of materials for each function is the key to a representative composite system. Correspondingly, arrangements and bond between elements of the composite structure are significant.

Due to the extensive development of material technology, composite structures are gaining popularity in the construction sector. Besides, high demands for low and medium cost houses, lack of construction workers and rising material cost led researchers and institutes to focus on composite building components.

The slab structure occupies the most significant dead load and volume in most of the residential buildings. Approximately 50 to $65 \%$ of a whole building dead load is coming from the slab structures. Moreover, this large self-weight percentage of the structure is playing a vital role in column, beam and foundation size, therefore, seismic capacity and response of ordinary residential buildings. Thus, a small reduction of weight or increase in load carrying capacity of this structure element will affect entire structure from design to construction and service life. This attractive, vital roles of the slab structure led the researcher to look for different composite and precast composite slab alternatives.

Several different types of composite slab structures have been used all over the word successfully. Most common composite slabs comprise of a profiled steel decking as a permanent formwork to the underside of the concrete slabs spanning between support beams. As far as composite concept concerns, 
difficulties in construction automatically escalate. Castings or assembling of the composite structure is also tricky when numbers of the elements used in the composition are increased.

As an alternative, precast concrete slab offers an economical and versatile solution for many different types of structures. It provides both design and cost advantages over traditional methods such as cast in-situ concrete, steel-concrete composite, and timber floors. There is a wide range of slab types available to give the most economical solution for all required loading and spans. Some of the precast systems eliminate formwork and reduce scaffolding cost which forms the most significant percentage of slab construction price. Nevertheless, precast constructions also have some disadvantage on the traditional method such as extra care for connection, transportation difficulties, and cost, heavy machinery, and storage in the construction site.

More recent attention has focused on precast composite slab system to overcome some of the drawbacks mentioned above. It combines composite slabs with precast concrete panels into one system. The system gives the advantages of precast and cast in situ by its composite formation. The precast layer of the composite system is placed as a permanent formwork and working platform, followed by in situ topping concrete. Therefore, conventional precast and cast in situ construction's difficulties such as transportation, fixing the steel bar, connection and joining problems are partially eliminated. Furthermore, the system provides a continuous connection between slabs and beams in the structure and shorter construction time. However, similar to other composite structures, integrity between the composite elements until the ultimate load remains as one the most significant concerns.

With a modification, in situ and precast construction are combined in such a way that most of the system's benefits can be obtained. This combined system is called half precast system or semi precast system. The best composite combination of the precast and cast in-situ systems were achieved by ferrocement precast slab system. Furthermore, the ferrocement precast slabs offer a lighter precast layer which provides easy construction and transportability. Utilizing ferrocement as a precast layer, the first structural crack load of the system is increased, and the crack occurrences during transport and handling will be minimized. With the natural thin form of ferrocement as precast layer leads to weight reduction of precast composite and reduce the amount of in-situ concrete. The present review aims to introduce studies on precast and composite precast ferrocement slabs and mechanical properties of ferrocement.

\section{Ferrocement in general}

From the early history of ferrocement and through its subsequent evolution, the definition of ferrocement has been changing. Ferrocement can be defined as a type of reinforced concrete $(\mathrm{RC})$ characterized by the small size of the reinforcement, which is wire mesh, and the aggregate, which is sand. The basic definition of ferrocement is given by ACI committee [1], however before and after this committee report, ferrocement has been defined with different researcher and committee [2-8].

Ferrocement was first patented by Joseph Lois Lambot and termed as Ferciment in 1856. One of his ferrocement boats is on display in a museum in Brignoles, France. However, there was insufficient application and research on ferrocement construction between 1888 and 1942. An Italian engineer, Pier Luigi Nervi, carried out a series of experiments on ferrocement after that period. Based on the tests, it is observed that reinforcing concrete with layers of wire mesh produces a material possessing the mechanical characteristics of an approximately homogeneous material which is capable of resisting high impact load. Nervi also applied the ferrocement concept to civil engineering structures and used the idea of corrugation for the roofs of several significant structures including a roof system spanning $98 \mathrm{~m}$ for the Turin Exhibition Hall. Ferrocement is now considered as a versatile, low-cost construction material with large potentials in many other areas, including housing applications. In many aspects, ferrocement is deemed to be an extension of $\mathrm{RC}$, and it has relatively better mechanical properties and durability than conventional RC. Within certain loading limits, it behaves as a homogeneous elastic material, and its elastic behavior is better than normal $\mathrm{RC}$. The uniform distribution and high surface area to volume ratio of its reinforcement results in a better crack arrest mechanism and higher first crack load. Moreover, ferrocement has better fire and heat resistance compared to RC [9-23].

The use of ferrocement technology seems to be an alternative to the current conventional systems. Ferrocement wall panels, precast ferrocement roofing elements, and ferrocement permanent formwork are few examples of ferrocement structural components being used in construction sector today.

\section{Mechanical properties}

\subsection{Tension}

Similar to reinforced concrete, the tensile behavior of ferrocement depends on mortar mix and wires as reinforcement. In addition to that, the ferrocement volume fraction acts on the tensile character dominantly. Under direct tensile load, ferrocement works as a homogeneous elastic material up to the first crack. It is assumed that no slippage occurs at the surface of fibers inelastic range. With the basic understanding of composite material laws for continuous fiber in the direction of load, the total weight is shared between the fibers and the matrix. Therefore, the equation can be written as follows:

$$
\begin{gathered}
F_{T}=F_{f}+F_{m} \\
\sigma_{T} A_{C}=\sigma_{f} A_{f}+\sigma_{m} A_{m}
\end{gathered}
$$




$$
\begin{aligned}
& v_{m}=\frac{A_{m}}{A_{c}} \\
& v_{f}=\frac{A_{f}}{A_{c}}
\end{aligned}
$$

Similarly

$$
E_{T}=E_{f} v_{f}+E_{m} v_{m}
$$

The modulus of elasticity of ferrocement in the un-cracked range was theoretically derived with the following expression by considering geometry and orientation of the mesh [9]:

$$
E_{T}=E_{f} v_{f}+E_{m} v_{m} \eta
$$

Where $E_{c}, E_{m}$, and $E_{f}$ are the moduli of elasticity of the composite, mortar, and mesh respectively; $v_{m}$ and $v_{f}$ are the volume fractions of mortar and mesh in the loading direction, and $\eta$ is the effectiveness factor of the mesh. The effectiveness factor is dependent on the geometrical properties of the mesh and its orientation.

The formation of the first crack is found to be the function of the specific surface of reinforcement [15] the first crack stress, $\sigma_{c r}$, may be optioned from

$$
\sigma_{c r}=24.52 S_{L}+\sigma_{m u}
$$

Where $S_{L}$ is the specific surface of the reinforcement in loading direction in $\mathrm{mm}^{-1}$ and $\sigma_{m u}$ is the ultimate strength of the mortar in direct tension in $\mathrm{MPa}[9]$.

$$
s_{L}=\frac{N \pi d_{1}\left(N_{1}\right)+\pi d_{2}\left(N_{2}\right)}{A_{m m}}
$$

Where $N$ is the number of layers, $N_{1}$ is the number of wire in one layer, $N_{2}$ is bar number, and $A_{m m}$ is the cross-section area of the mortar. However, another formula was suggested for the specific surface of reinforcement in the longitudinal direction $\left(S_{r L}\right)$ [19].

$$
S_{r L}=\frac{P}{A_{C}} \cong \frac{P}{A_{m}}
$$

Types, size, and volumes of wire meshes have a significant influence on elastic, cracking and the ultimate behavior of ferrocement in axial tension [19]. The theoretical formula for the prediction of average crack spacing was developed based on those factors. The formula is the same as the one Robinson [20] derived from conventionally reinforced concrete. For mathematical formulation, it was assumed that the average crack spacing is $\phi=1.5$ times the minimum and the ratio of bond strength between the mesh and mortar to the tensile strength of the mortar is $\eta=1.6$ [19].

Theoretica 1 Crack spacing $=\frac{\varphi}{\eta} * \frac{1}{S_{L}}=\left(\frac{1.5}{1.6}\right) *\left(\frac{1}{S_{L}}\right)$

Similar the cracking load of the composite is expressed in another study as [20]

$$
P_{c r}=f_{m u}\left(A_{m}+m A_{s}\right)
$$

Where $P_{c r}$ is the cracking load, $f_{m u}$ is the ultimate tensile strength of mortar, $\mathrm{m}$ is the modular ratio $\left(E_{s} / E_{m}\right)$ and $A_{m}, A_{s}$ are the cross-section areas of mortar and steel, respectively. In that study, it was found that value of the slip modulus, the ultimate bond strength and the modulus of elasticity of mortar have negligible influence on crack spacing. The parameters which significantly affect the crack spacing are the ultimate tensile strength of mortar and volume fraction of mesh reinforcement [20]. The crack width is greatly influenced by volume fraction, modulus of elasticity of steel and ultimate bond strength. Beside this literature, many specific studies have been compiled on tensile stress of ferrocement, and it could be referred [21].

\subsection{Compression}

The ferrocement compression behaviors are controlled mostly by properties of the cementation mortar matrix. Thus, the standard parameters known to regulate the compressive strength of concrete, such as water-to-cement ratio and cement content are also effective in ferrocement compressive strength. Early research shows that there is a minimum increment of ultimate strength due to reinforcement for ferrocement under compression [24]. On the other hand, based on experimental data, it was concluded that ultimate compressive strength of the composite is lower than that of an equivalent pure mortar [15].

Considerable diversity was recorded in the compression test result regarding strength, strain and elastic modulus [25]. Finally, it is found that for low mesh content, the compressive strength of ferrocement is smaller than that of the matrix alone. However, the compressive strength picks up again at higher mesh content[8]. For the design purpose, many suggestions are given[26]. However, it is common to consider that the compressive strength of ferrocement is the same as that of the mortar matrix. When favorable parameters are not present, it is reasonable to design for a compressive strength equal to 80 percent of that of the mortar matrix [8].

\subsection{Flexure}

Flexural properties reflect the combined influence of parameters controlling not only tensile and compression but also shear properties. Moreover, it is believed that the nature of the mesh reinforcement, by having reinforcement in two directions, both laterally and longitudinally, generally imparts some additional strength and safety when flexural is considered in one direction only (one-way bending). In ferrocement generally, the wire meshes are uniformly distributed over the entire section. The skeletal steel which helps provide the proper shapes and form are placed in both directions with wider spacing. The skeletal steel in the longitudinal direction has partially no contribution within the elastic range due to its 


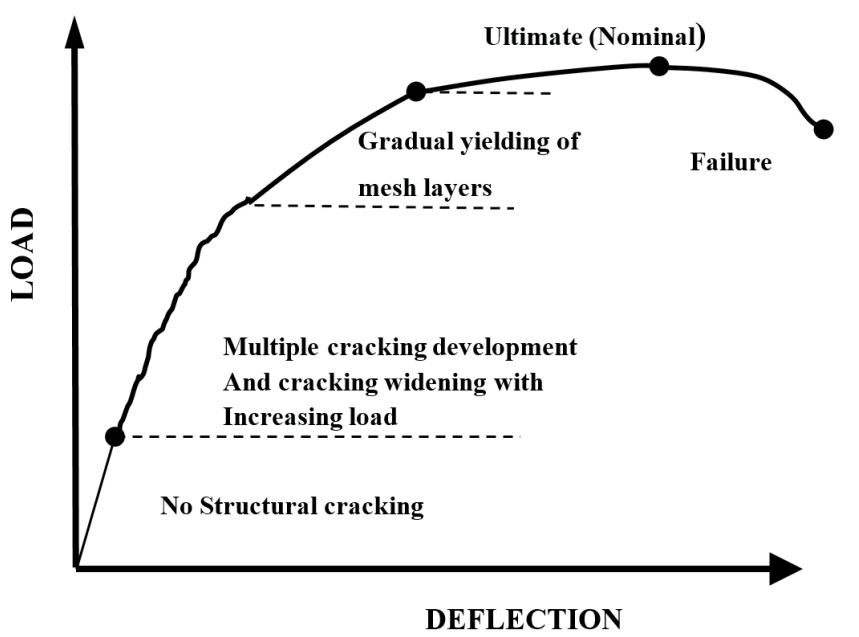

Fig. 1 Typical load-def. Response of Ferrocement

proximity to the center of the section. However, under ultimate stress conditions, it has a significant contribution to resisting the ultimate structural failure [9] [24].

Several portions of the typical load-versus-deflection response of ferrocement in bending can be identified ( Fig. 1): (1) an initial part where structural cracking does not occur; (2) a multiple cracking region where cracks develop and their width increases with increasing load; (3) an area where gradual yielding of the steel reinforcement occurs; (4) a post-yielding plastic or strain-hardening region during which the maximum or ultimate load is attained; (5) a post-peak portion where failure occurs either due to mortar failure in compression or due to failure of the extreme layer of mesh.

Ferrocement beam tests have been carried out by evaluating the first crack stress in bending $\left(\sigma_{c r b}\right)$ [27]. The first crack stress in bending in the extreme mortar fiber was found to be linearly related to the specific surface of the reinforcement in the tension zone $\left(S_{L T}\right)$. From regression analysis the following relationship was obtained in the study;

$$
\sigma_{c r b}=280.20 S_{L T}+\sigma_{m r}
$$

Where $S_{L T}$ is the ratio of the surface area of reinforcement in the longitudinal direction, and the initial mortar volume in the tension zone in $\mathrm{mm}^{-1}$ and $\sigma_{m r}$ is the modulus of rupture of the mortar in MPa. Another experimental work shows that the first crack stress $\sigma_{c r}$ in bending is a linear function of the percentage of steel reinforcement, $p$ and an empirical relation is suggested as follows [28];

$$
\sigma_{c r}=1.96 p+3.33
$$

A series of tests shows that observation and detecting of the first crack of ferrocement depend on many parameters and the following conclusions were drawn from crack-detection studies:

i. Ferrocement with large diameter reinforcing mesh is much stronger than that with a significant amount of smaller-diameter reinforcing mesh. But it is much less resistant to crack. ii. If the wire mesh inside a specimen was unevenly distributed, then a 'closing up' effect might occur which will cause premature cracking of a sample. It is challenging to determine the position of the wire mesh inside ferrocement.

iii. Very small first crack widths are not only difficult to find, using any method, but often do not occur. For example, a specimen might be loaded up to $4.0 \mathrm{kN}$ without cracking, and then at $4.1 \mathrm{kN}$, a 50 -micron crack might appear. This crack has grown from nothing to a 50-micron crack in the space of one load increment, and it was not obvious where the 20-micron crack occurred [29].

iv. The percentage of transfer wires in the mesh reinforcement of ferrocement enhances bond transfer properties and directly affects cracking characteristics.

\subsection{Shear}

Most of the applications of ferrocement have been in structures where high tensile strength or small crack width is the governing criterion [30]. Therefore, not much research work has been done on ferrocement under direct shear. Ferrocement under direct shear exhibits two stages of behavior namely cracked and un-cracked while ferrocement under flexure exhibits a third stage (ultimate or plastic stage) in addition to the un-cracked and cracked stages. Hence ferrocement is less ductile under shear than flexure. Another critical behavior to notice is that the duration of the cracked phase in ferrocement under direct shear increases with increasing amount of wire mesh reinforcement.

The cracking and ultimate shear stresses of ferrocement increase with increasing mortar strength and wire mesh reinforcement; they can be predicted by the following empirical formula [31]:

$$
\begin{gathered}
\tau_{c r}=f_{t}+450 V_{f}(M P a) \\
\tau_{u l t}=f_{t}+900 V_{f}(M P a)
\end{gathered}
$$

Where; $\tau_{c r}$ is the cracking shear stress, $\tau_{u l t}$ is the ultimate shear stress, $f_{t}$ is the mortar tensile strength, and $V_{f}$ is the volume fraction of wire mesh.

\section{Ferrocement composite and precast applications}

With its versatility, ferrocement is a promising element for composite structures. Therefore, many composite slab and roof elements applications have been carried out with ferrocement. The primary goals in developing a composite precast slab system are based on the following ideas: increasing constructability capacity for the different structure, decreasing unnecessary dead load, reduce total cost of the structure, improve sound and thermal insulation capacity and last but not least increasing the speed of construction. With this advice in mind, the section which is between compression and tension zone and under neutral axis located at the core of the slab is the most suitable location to decrease the total weight of a slab. 
A light-weight slab system is introduced with a specially-produced empty box which is placed in the core of the slab and acts as a weight-decreasing component. The system can be considered a step to understanding the composite panel action. This system consists of three parts; the skin element which is ferrocement and acts as permanent formwork while at the same time providing tension reinforcement; a ferrocement hollow box, which is the second element of composite slab and create voids at core section; the in-situ concrete with steel rods cast on top of the skin and ferrocement hollow-box element. The final product is a waffle slab but with a different construction method. The system is almost 50\% lighter than the solid slab. The $220 \mathrm{~mm}$ thick hollow slab (with two layers of hexagonal mesh) is adequately strong, without any steel bars as flexural reinforcement, up to a span of $3 \mathrm{~m}$ for a working load level of $100 \mathrm{~kg} / \mathrm{m}^{2}$ [32].

The aircraft industry's application of the light-weight, high strength concept is an excellent example to show the specific role of every part of the composite ferrocement panel structure [33]. The system consists of two facing elements which are ferrocement and one core element between them. However, the application of this system to building structures is beyond the traditional method of construction. The slab structure is divided into three aspects according to the function of each in the composition. Different functions, such as tension, compression, and shear, were proposed for each component: accordingly, different materials were introduced to fit these functions. Several significant considerations were suggested in this study: materials with a strength of 10 to $15 \mathrm{MPa}$ are found to be sufficient as core elements. Materials in the core of the structure should be workable, lightweight and have the ability to transfer horizontal shear stress. With lightweight aggregates, several mix proportions are possible to achieve low weight, high workability mix (1145 Kg/m ${ }^{3}$ and $\left.13.3 \mathrm{MPa}\right)$ [34].

A different system, known as composite ferrocement brick slab, has been used in India. This system is currently used for small-scale construction and in the rural sector for roofing purposes India and China. Non-structural bricks are laid on the formwork with precise spacing, and 10-12-mm diameter steel bars are placed between the bricks. A certain depth was provided as concrete cover by using a concrete spacer. Then, in-suite concrete was placed between and top of bricks [34]. The primary defect in Reinforced Brickwork (RB) is that bricks absorb moisture and this creates an acidic environment in which the reinforcement is corroded. In the present case, it is purposed to use ferrocement as the bottom layer of RB slabs with the intention that masonry will resist compression and both traditional reinforcement and mesh reinforcement will withstand tension [7, 35].

A further step for brick slab research has appeared as the semi-precast composite brick slab. Brick infills in precast ferrocement inverted channels were used as flexural members.
This channel section is ending with secondary ribs. For the connection of the precast ferrocement and the bricklayer, the roughness of both layers was thought to be adequate. The analysis of the composite section was carried out assuming the bond between the precast unit and in-situ brick infill is not disturbed until failure load is reached. The study was carried out on both the ferrocement precast layer alone and the ferrocement precast layer with infill bricks. It was found that during the loading, compressive strain measured on the top surface of the brick infill were more or less the same as those measured on top of the ribs. This result shows that full composite action was carried out at the first loading stages. However, towards the ultimate load stage, the ribs of the ferrocement trough started deflecting sideways, and the bond between the ribs and brick infill was partly broken [36].

One of the significant milestones of the composite precast slab system is half-precast slabs. The system is similar to the composite slab system, which is a combination of a profiled steel deck and topping concrete. In the half-precast slab system, a thin concrete precast element, which is sometimes called as permanent formwork, is used in place the profiled steel deck. This thin precast element is produced from ferrocement due to its high performance as a thin structure. In favor of increasing the stiffness, ferrocement thin panel is formed with longitudinal or both longitudinal and transfer inverted ribs. Alternatively, some of the researchers used ferrocement as a precast folded plate [37]. Precast ferrocement structures appeared as roof elements at early stages of its development. Many different types of the section were tried as precast elements, and a comparison was made between each precast and composite system. [38-41]

A comparison study between slabs made with a profiled steel deck (Corrugated galvanized iron "CGI") and those made with a ferrocement deck shows that the ferrocement composite exhibits better performance as compared to CGI composites concerning load carrying capacity, energy absorption capacity, ductility and recovery in unloaded condition [42]. Besides, the steel deck (CGI) slab fails at horizontal shear after service load while ferrocement structure has better performance on this aspect due to its rough surface. Even though, replacing the cold-formed steel deck with same-shaped ferrocement panel shows better integrity, the separation between the layers at ultimate load leads to the same unavoidable end [43].

Precast ferrocement composite systems have been used with inverted ribs to obtain a better response regarding temporary loads and horizontal shear response after construction. This precast element consists of thin skin and ribs. Plates between the ribs must offer the required resistance to the applied construction load. Based on these conditions, two meshes were found to be sufficient for structural safety. The floor slab in this study was designed with main ribs $155 \mathrm{~mm}$ in depth, secondary ribs of slightly less depth, and a 15-20 mm ferrocement plate. The final product is nothing else but a concrete 
slab; therefore weight, thermal and acoustic insulation performances are the same as a solid concrete slab [44, 45].

A unique layout was applied for the slab with two-way ribs: the sides of the slab were arranged to from side beams which can easily connect with columns [46]. Same researchers further improved the system; the layout was kept the same, but the depth of slab was decreased from 330 to $220 \mathrm{~mm}$. It is found that the system is lighter than the full precast slab. But, the connection rigidity at supports of the system is higher than conventional complete precast system [47].

Another inverted ribbed system was fabricated out with a thinner depth $(185 \mathrm{~mm})$. This system was also designed to carry all loads including construction, handling, walking on the surface layer or top layer, and structural live and dead loads. Load-deflection properties for two and four layers of wire mesh are not significantly different under a service load [48]. Therefore two-layer wire mesh reinforcement is found to be more proper for the system.

The testing of ferrocement ribbed slabs suggests that it has many valuable applications in building structures. The system could be easily adapted for high-rise buildings and can be manufactured with different techniques. Moreover, the system could be designed as a one-way ribbed slab up to $8.7 \mathrm{~m}$ for a $1.92 \mathrm{kN} / \mathrm{m}^{2}$ life load. With all these benefits in mind, a cost comparison shows that this system is $47 \%$ cheaper than cast in-situ RC for a 20- story building [49].

In recent years, significant studies have carried out on ferrocement advantages in structural engineering applications [14, $50,51]$. Ferrocement use in the precast and composite precast application provides a practical and quality choice in industrial building systems (IBS). Employment of modern precast technology by using bolted connections to assemble precast construction material was introduced by Naaman et al. [52, 53]. The system was developed further by investigating the critical parameters which affect bolted joints, such as the thickness of the connected ribs and location of bolts. The study suggested a simple analytical design for ferrocement bolted joints [54].

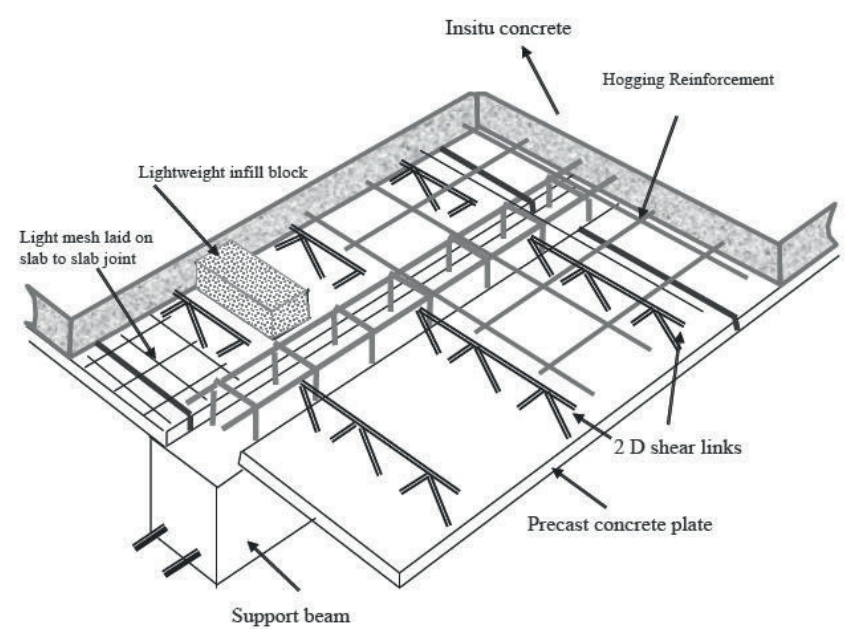

Fig. 2 Ferrocement brick masonry slab connected with lattice girders (shear links)
A new system was developed by Waleed et al., consisting of a bottom ferrocement skin, brick masonry, and in-situ mortar ribs. The ferrocement layer is the precast part of the composite slab, which includes a wire mesh and steel reinforcement, required to resist the tensile stresses as shown in Fig. 2. The thickness and reinforcement of this layer will depend mainly on the span of the slab. The bricklayer, as lightweight infill block, and the in-situ ribs provide the necessary resistance to the compressive forces developed due to bending.

The two layers are interconnected using truss-type shear connectors (Fig. 3). The advantages of this system, amongst others, are it's relatively lightweight compared to R.C which will reduce the load transferred to the beams/walls. The masonry bricks act as light (especially voided brick), natural, cheap, effective insulation material and at the same time partially resist the compression forces developed due to bending of the composite.

However, this connection system has been questioned by many researchers [55-59]. Studies show that the structure responds to composite slab sound behavior till service load. The efficiency of connection between two layers of the composite system under ultimate loads remains a significant concern for such system. Thus, the ability of the shear trusses to be shear connectors for composite two layers are yet to be explored.

The ferrocement brick masonry slab further improved by replacing steel lattices by interlocking ribs [60-63]. This interlocking system is developed with the aim of gaining as many benefits as possible during and after construction. Precast layer cast in the form of ribbed slabs but ribs are engaged differently from other ribbed slabs encountered in practice. This precast element has their ribs above the plates, which is ferrocement when they are in place in the system as shown in Fig. 4. The ribs have a versatile function in the system; it is concerned both flexural soundnesses of the precast layer and shear soundness for composite system. As a cumulative effect, the system can reduce the duration of construction with having at least the same ability to perform satisfactorily as what can be achieved by a conventional concrete slab.

On-site, the construction of the composite slab does not require heavy equipment to handle the ferrocement layer. Furthermore, the construction does not need any formwork since the bottom layer of ferrocement is a precast unit that can be easily fixed in position, using a simple crane, to provide a platform that acts as a formwork for the bricklayer and the in situ concrete ribs.

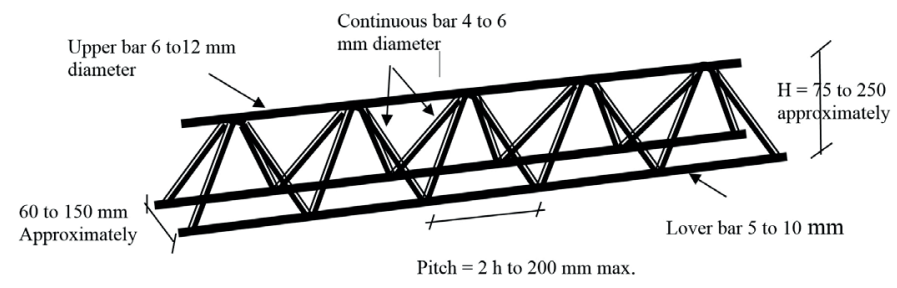

Fig. 3 A typical shear connector, lattice girder, for composite precast slabs systems. 


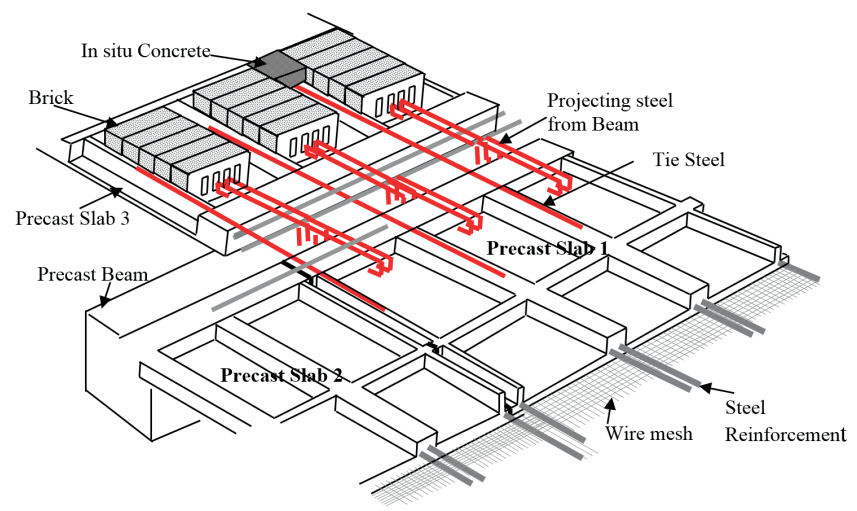

Fig. 4 interlocking composite ferrocement precast masonry slab

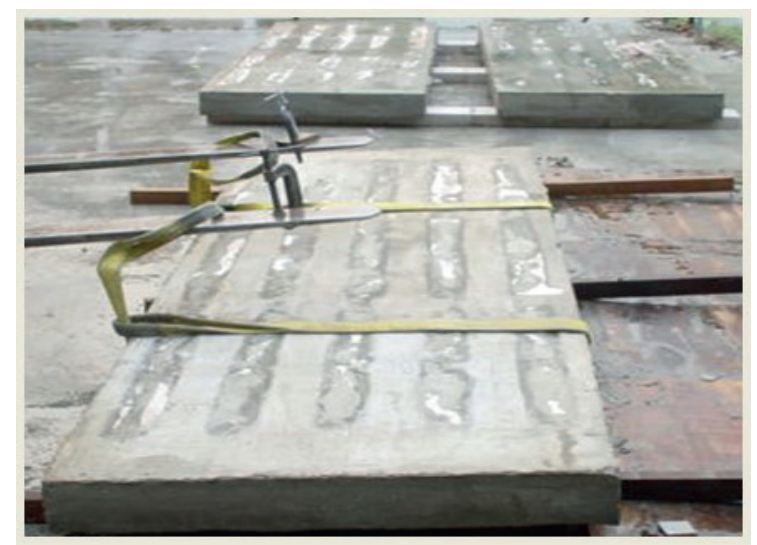

Fig. 5 AAC-concrete lightweight precast ferrocement composite floor slab

Yavuz et al. have further improved the system., by replacing bricks by autoclaved aerated concrete (Fig. 5) [12, 63, 64]. This system demonstrates that the weight of the slab structure may be reduced 20 to 35 percent without sacrificing load-carrying capacity.

\section{Results}

Ferrocement precast slabs were involved with new ideas, and mechanical capacity was enhanced with a different type of applications and materials [11, 65]. With these improvements, the ferrocement gaining popularity back with its versatility and cost-benefit and continuing its journey from the invention. Lately, ferrocement performance studies on seismic and fire resistance, crack repairment and strengthening of both unreinforced and reinforced masonry were proven its multifunctional benefits. The most significant contribution of ferrocement is resisting the first crack load. It provides the significant contribution to service load, fire resistance and corrosion resistance with this feature. [66-70]. These remarkable studies once more prove that the ferrocement precast composite technology has a wide practical application with many advantages, and also inspired the effort in this study to find an even more efficient design for ferrocement composite panels.

However, applications of the precast composite slab or ferrocement composite slab systems are still a concern for the structures which are built at an area under seismic risk. Although lightweight future of the systems provides benefits to decrease total mass of the structure, therefore, the total seismic force applied to it, diaphragm rigidity provided with this type of slab system needs to be investigated deeper. Moreover, using ferrocement as concrete cover for ordinary $\mathrm{RC}$ structure members has enormous potential to address some of the shortcomings of concrete cover, first crack load, reinforcement corrosion resistance and fire resistance.

\section{Conclusions}

This paper investigated ferrocement use in the precast slab and composite precast slab applications. The utilizing of ferrocement in precast technology is highlighted regarding the mechanical and in-service properties. The advantages of ferrocement can be realized from its potential in precast and precast composite application. The flexibility of ferrocement provides for the design of panels that are thin, durable and have a high first crack load, which results in reduced construction time and total cost of the precast elements. Despite its thin structural form, ferrocement shows ductile behavior resulting in flexible transportation and erection options for the precast structures. Research conducted over the past decades demonstrates the advantages of ferrocement composite precast panels and suggests that new designs have the potential to overcome most of the precast and the precast composite structures' shortcomings. The use of ferrocement as a permanent formwork, concrete cover, precast slab, precast half slab and precast composite slab have proved its advantageous characteristics. Based on this review of research on ferrocement, it is evident that usage of the ferrocement should continue to be an important research focus for precast composite slab applications.

\section{References}

[1] Batson, G. B., Castro, J. O., Guerra, A. J., Iorns, M. E., Johnston, C. D., Naaman, A. E., Zubieta, R. C. "Guide for the Design, Construction, and Repair of Ferrocement". ACI Structural Journal, 85(3), pp. 325-351. 1988. https://doi.org/10.14359/3527

[2] Pama, R. P. "Ferrocment - An Overview Keynote Lecture". In: Ferrocement: Proceedings of the Fifth International Symposium. (Nedwell, P. J., Swamy, R. N. (Eds.)), pp. 3-18. Taylor \& Francis, London. 1994.

[3] Shah, S., Naaman, A. E. "Tensile Tests of Ferrocement". ACI Journal of Ferrocement, 68(9), pp. 693-698. 1971.

https://doi.org/10.14359/7233

[4] Riley, R. O. N., Turner, J. M. M. "Fishing Boat Construction: 3. Building a Ferrocement Fishing Boat". FAO FISHERIES TECHNICAL PAPER 354. Rome, 1995. http://www.fao.org/3/a-v9468e.HTM

[5] Palotas, L. "Design And Crack Prediction Of Steel Wire Reinforced Concrete". Periodica Polytechnica Civil Engineering, 22(1-2), pp. 69-78. 1978.

[6] da Silva, A. R. C., Proença, S. P. B., Billardon, R., Hild, F. "A Probabilistic Approach to Predict Cracking in Lightly Reinforced Microconcrete Panels". Journal of Engineering Mechanics, 130(8), pp. 931-941, 2004 https://doi.org/10.1061/(ASCE)0733-9399(2004)130:8(931)

[7] Kaushik, S. K., Gupta,V. K., Anuj, S. K. "Behavior and Performance of Composite Ferrocement Brick Reinforced Slabs". Journal of Ferrocement, 21, pp. 215-222. 1991. 
[8] Naaman, A. E. "Ferrocement and Thin Fiber Reinforced Cement Composites: Looking Back, Looking Aheade". In: Seventh International Symposium on Ferrocement and Thin Reinforced Cement Composites. pp. 3-16. Singapore. 2001.

[9] Paul, B. K., Parma, P. R. "Ferrocement". International Ferrocement Info Center, Bangkok: 1978.

[10] Swamy, R. N. "New Reinforced Concretes". Blackie, London. 1984.

[11] Chithambaram, S. J., Kumar, S. "Flexural behaviour of bamboo based ferrocement slab panels with flyash". Construction and Building Materials, 134, pp. 641-648. 2017. https://doi.org/10.1016/j.conbuildmat.2016.12.205

[12] Yardim, Y., Waleed, A. M. T., Jaafar, M. S., Laseima, S. "AAC-concrete light weight precast composite floor slab". Construction and Building Materials, 40, pp. 405-410. 2013. https://doi.org/10.1016/j.conbuildmat.2012.10.011

[13] Yerramala, A., Ramachandurdu, C., Desai, V. B. "Flexural strength of metakaolin ferrocement". Composites Part B: Engineering, 55, pp. 176-183. 2013. https://doi.org/10.1016/j.compositesb.2013.06.029

[14] Greepala, V., Nimityongskul, P. "Structural integrity of ferrocement panels exposed to fire". Cement and Concrete Composites, 30(5), pp. 419 430. 2008 https://doi.org/10.1016/j.cemconcomp.2007.08.007

[15] Pama, R. P., Intaragumhaeng V, P. B. "Study of Tensile cracks and bondslip in ferrocement". Ferrocement materials and applications, SP-61, pp. 43-79. Detroit. 1979.

[16] Lilia, R.-A. "Evolution of Ferrocement". In: Seventh International Symposium on Ferrocement and Thin Reinforced Cement Composites. Singapore. 2001.

[17] Naaman, A. E. "Ferrocement and laminated cementitious composites". Materials and Structures, 33(2), pp. CO3-CO3. 2000. https://doi.org/10.1007/BF02484171

[18] Huq, S., Pama, S. R. "Ferrocement in Tension: Analysis and Design". Journal of Ferrocement, 8(3), pp. 143-167. 1978.

[19] Naaman, A. E. "Design Predictions of Crack Width in Ferrocement". Ferrocement-Materials and Applications, 61, pp. 25-42. 1979.

[20] de Robinson, J. R. Cours de Beton Arme-de I'Ecole nationale des ponts et Chaussess. Paris, Dunod. 1964.

[21] Akhtaruzzaman, A. K. M., Pama, R. P. "Cracking Behavior of Ferrocement in Tension". Journal of Ferrocement, 19, pp. 101-108. 1989.

[22] Yardim, Y., Lalaj, O. "Shear strengthening of unreinforced masonry wall with different fiber reinforced mortar jacketing". Construction and Building Materials, 102(Part 1), pp. 149-154. 2016. https://doi.org/10.1016/j.conbuildmat.2015.10.095

[23] Nguyen, H. T., Thanh, N. H. "The Water-Demand And Gap-Volume Of Aggrgate For Ferrocement". Periodica Polytechnica Civil Engineering, 33(1-2), pp. 85-106. 1989.

[24] Rao, A. K., Gowdar, C. S. K. "A Study of Behaviour of Ferrocement in Direct Compression". Cement and Concrete,10, pp. 231-237. 1969.

[25] Rao. P. K. "Stress-Strain Behavior of Ferrocement Elements under Compression". Journal of Ferrocement, 22(4), pp. 343-352. 1992.

[26] Arifa, M., Pankaj, Kaushik, S. K. "Mechanical behaviour of ferrocement composites: An experimental investigation". Cement and Concrete Composites, 21(4), pp. 301-312. 1999. https://doi.org/10.1016/S0958-9465(99)00011-6

[27] Logan, D., Shaw, S. P. "Moment Capacity and Cracking Behavior of Ferrocement in Flexure". ACI Journal Proceedings, 70(12), pp. 799-804. 1973. https://doi.org/10.14359/7137

[28] Kumar, S. G. V., Sharma, P. C. "Investigation of the Ultimate and First Crack Strengths of Ferrocement in Flexure". Indian Concrete Journal, 50(1), pp. 335-340,344. 1976.
[29] Seed, J. P., Nedwell, P., Vickridge, I. "Accurate crack measurement in ferrocement". Journal of Ferrocement, 19(1), pp. 1-10. 1989.

[30] Basunbul IA, Al-Sulaimani GJ, Saleem M, Al-Mandil M Y. Rookee, "Behaviour of Ferrocement Roof Panels". In: Proceedings of the Third International Symposium on Ferrocement, pp. 258-261, University of Roorkee. Roorkee, 1988.

[31] Paramasivam, P., Mansur, M. A., Ong, K. C. "Flexural Behaviour of Lightweight Ferrocement Slabs". Journal of Ferrocement, 15(1), pp. 25-33. 1985.

[32] Suleiman, M., Maher, A., Brohi, P. "Ferrocement Hollow Box Roof Slab". Journal of Ferrocement, 15(1), pp. 35-39. 1985.

[33] Swamy, R. N. "Application of Ferrocement Concept to Low Cost Lightweight Concrete Sandwich Panels". Journal of Engineering Mechanics, 18(3), pp. 285-292. 1988.

[34] Kumar, S. "Treasure of R. C. C. Designs". Standard Book, Delhi. 1990.

[35] Adlakha, P. K., Puri, H. C. "Prefabrication building methodologies for low cost housing". Journal of The Institution of Engineers, 84(1), pp. 4-9. 2003.

[36] Paramewaran, V. S., Krishamoorthy, T. S., Neelamegam, M. B. K. "Investigations on Precast Composite Ferrocement Brick-Infilled Flexural Members". In: Proceedings of 3rd International Conference on Ferrocement, pp. 544-550, University of Roorkee, Roorkee, 1988.

[37] Kaushik, S. K., Gupta, V. K. "Behavior of Ferrocement folded plate Roofs". In: Proceedings of 3rd International Conference on Ferrocement, pp. 335-343, University of Roorkee. Roorkee, 1988.

[38] Ganesan, T. P., Kalyanasundaram, P., Mathews, M. S. "Development and Proof-Testing of a Ferrocement Roofing System". In: 3rd International Conference on Ferrocement, pp. 437-444. University of Roorkee, Roorkee, 1988.

[39] Hago, A. W., Al-Jabri, K. S., Alnuaimi, A. S., Al-Moqbali, H., Al-Kubaisy, M. A. "Ultimate and service behavior of ferrocement roof slab panels". Construction and Building Materials, 19(1), pp. 31-37. 2005. https://doi.org/10.1016/j.conbuildmat.2004.04.034

[40] Narayanaswamy, V. P., Kuma, G. V. S., Sharma, P. C. "Precast Ferrocement Trough Element For Low-Cost Roofing". Journal of Ferrocement, 2(1), pp. 77-84. 1981.

[41] Lee, S.L., Paramasivam, P., Tam, Chat-Tim. Ong, K., Tan, Kiang K. H., "Ferrocement: Alternative Material for Secondary Roofing Elements". ACI Materials Journal, 87(4). 1990. https://doi.org/10.14359/2118

[42] Kaushlk, S. K., Gupta, V. K., Singh, K. T. "Behavior of Composite Slabs with Lost Formwork". Journal of Ferrocement, 21(3). 1991.

[43] Mansur, M. A., Ong, K. C. G. "Composite Behavior of FerrocementDeck- Rei nforced Concrete Slabs". Journal of Ferrocement, 16(1), pp. 13-21. 1986.

[44] Blugert, F., Tatsa, E. Z. "Skinned Elements Made of Ferrocement for Building”. Journal of Ferrocement, 9(1), pp. 35-40. 1979.

[45] Sarid, M, Tatsa, E. Z., Bljuger, F. "Ribbed Slab Made of Ferrocement". Journal of Ferrocement, 9(4), pp. 185-190. 1979.

[46] Tatsa, S. Moses, A., Omorodion, T. "Multistory Construction Using Precast Underreinforced Ferrocement Panels". Journal of Ferrocement, 11(1), pp. 67-77. 1981.

[47] Omorodion, T. "Analysis and Design of ferrocement Ribbed Slabs". University of New York. 1983.

[48] Basavarajaiah, B. S., Krishna, H. V., Verkata, V. B. "Flexural Behaviour of Precast Ribbed Ferrocement Slabs an Experimental Study". In: Proceedings of the 2nd International Symposium on Ferrocement, pp. 213224, 1985.

[49] Tatsa, E. Z. "Construction with ferrocement panels". Journal of Ferrocement, 18(1), pp. 17-33. 1988. 
[50] Shannag, M. J. "Bending behavior of ferrocement plates in sodium and magnesium sulfates solutions". Cement and Concrete Composites, 30(7), pp. 597-602. 2008.

https://doi.org/10.1016/j.cemconcomp.2008.03.003

[51] Memon, N. A., Sumadi, S. R., Ramli, M. "Performance of high wokability slag-cement mortar for ferrocement". Building and Environment, 42(7), pp. 2710-2717. 2007.

https://doi.org/10.1016/j.buildenv.2006.07.015

[52] Naaman, A. E. "Ferrocement Housing: Toward lntergrated High Technology Solutions". Journal of Ferrocement, 19(2), pp. 141-149. 1988.

[53] Naaman, A. E., Hammoud, H. "Ferrocement prefabricated housing: the next generation". Journal of Ferrocement, 22, pp. 35-47. 1992.

[54] Mansur, M. A., Tan, K. L., Naaman, A. E. "Strength of bolted moment connections in ferrocement construction". Cement and Concrete Composites, 32(7), pp. 532-543. 2010.

https://doi.org/10.1016/j.cemconcomp.2010.04.001

[55] Yee, A. A. "Structural and Economic Benefits of Precast/Prestressed Concrete Construction". PCI Journal, 46(4), pp. 34-42. 2001.

[56] Seangatith, S. "Experimental Investigation on Flexural Behaviors of Precast Prestressed Concrete Slabs Externally Strengthened With Steel Plates". In: The Ninth East Asia-Pacific Conference on Structural Engineering \& Construction, pp. MMR 54-59 Bali, Indonesia, December 16-18, 2003.

[57] Seangatith, S. "Experimental Investigation on Flexural Behaviors of Precast Prestressed Concrete Slabs Externally Strengthened With Steel Plates". In: The Ninth East Asia-Pacific Conference on Structural Engineering \& Construction, pp. 16-18, Bali, Indonesia. 2003.

[58] Engström, B. "Ductility of Tie Connections for Concrete Components in Precast Structures". Chalmers University of Technology. 1992.

[59] Taheri, H., Hejazi, F., Vaghei, R., Jaafar, M. S., Ali, A. A. A. "New precast wall connection subjected to rotational loading". Periodica Polytechnica Civil Engineering, 60(4), pp. 547-560. 2016. https://doi.org/10.3311/PPci.8545

[60] Thanoon, W. A., Yardim, Y., Jaafar, M. S., Noorzaei, J. "Structural behaviour of ferrocement-brick composite floor slab panel". Construction and Building Materials, 24(11), pp. 2224-2230. 2010.

[61] Thanoon, W. A., Yardim, Y., Jaafar, M. S., Noorzaei, J. "Development of interlocking mechanism for shear transfer in composite floor". Construction and Building Materials, 24(12), pp. 2604-2611. 2010. https://doi.org/10.1016/j.conbuildmat.2010.05.015

[62] Thanoon, W. A., Yardim, Y., Jaafar, M. S., Noorzaei, J. "Structural response of interlocking composite masonry slab". Proceedings of the Institution of Civil Engineers - Structures and Buildings, 164(6), pp. 409-420. 2011.

https://doi.org/10.1680/stbu.2011.164.6.409

[63] Yardim, Y. "Development of Lightweight Composite Slab System for Residential Building". University of Putra Malaysia. 2008.

[64] Thanoon, W. A., Yardim, Y., Noorzaei, J., Jaafar, M. S. "Structural Behaviour of Ferrocement-Brick Composite Slab". In: 6th International Congress on Advances in Civil Engineering, 6-8 October 2004, Bogazici University, Istanbul, Turkey, https://www.researchgate.net/profile/ Yavuz_Yardim/publication/258507393_Structural_Behaviour_of_Ferrocement-Brick_Composite_Slab/links/0c96052861a705cda7000000.pdf

[65] Cheah, C. B., Ramli, M. "Load capacity and crack development characteristics of HCWA-DSF high strength mortar ferrocement panels in flexure". Construction and Building Materials, 36, pp. 348-357. 2012. https://doi.org/10.1016/j.conbuildmat.2012.05.034

[66] Ganesan, N., Indira, P. V., Irshad, P. "Effect of ferrocement infill on the strength and behavior of RCC frames under reverse cyclic loading". Engineering Structures, 151, pp. 273-281. 2017. https://doi.org/10.1016/j.engstruct.2017.08.031
[67] Jayasree, S., Ganesan, N., Abraham, R. "Effect of ferrocement jacketing on the flexural behaviour of beams with corroded reinforcements". Construction and Building Materials, 121, pp. 92-99. 2016. https://doi.org/10.1016/j.conbuildmat.2016.05.131

[68] Hung, C. C., Chen, Y. S. "Innovative ECC jacketing for retrofitting sheardeficient RC members". Construction and Building Materials, 111, pp. 408-418. 2016

https://doi.org/10.1016/j.conbuildmat.2016.02.077

[69] Mustafaraj, E. Y. Y. "External shear strengthening of unreinforced masonry panels using ferrocement jacketing". In: XVI International Scientific Conference VSU'2016. Sofia. 2016.

[70] Mustafaraj, E., Yardim, Y. "In-plane Shear Strengthening of Unreinforced Masonry Walls Using GFRP Jacketing In-plane Shear Strengthening of Unreinforced Masonry Walls Using GFRP Jacketing". Periodica Polytechnica Civil Engineering, 62(2), pp. 330-336. 2017. https://doi.org/10.3311/PPci.11311 